\title{
Literature of Acquisitions in Review, 1996-2003
}

\section{By Barbara S. Dunham and Trisha L. Davis}

In this review, the authors discuss key trends in acquisitions found in the professional literature published from 1996 through 2003. During this period, technology surfaced as the primary factor affecting acquisitions policies and procedures. Advances in technology allowed vendors and libraries to select, order, and pay for materials via automated systems and the Internet. Such changes also allowed acquisition units to streamline many of their processes and improved efficiency. As the demand for electronic resources continued to grow, acquisition units frequently were restructured to meet the more complex acquisition process. Acquisitions librarians often were required to assume the responsibility for negotiating license agreements and establishing online access, and to handle the myriad issues required to manage electronic resources. The changes in technology were complex improvements to existing workflows; the addition of electronic resources management introduced significant new responsibilities to the acquisitions unit.

Barbara S. Dunham (dunham.51@osu .edu) is Assistant Professor, Serials and Electronic Resources Librarian, and Trisha L. Davis (davis.115@osu.edu) is Associate Professor, Rights Management Coordinator and Head, Serials, Electronic Resources and Rights Management Department, both at The Ohio State University Libraries, Columbus.

Submitted January 20, 2008; tentatively accepted and returned to authors January 14, 2008 for revision; revised and submitted June 17, 2008, and accepted for publication.
$\mathrm{T}$ he impact of technology on acquisitions and the place of acquisitions in the library organization figured prominently in Schmidt's review of acquisition literature of the early 1990s. ${ }^{1}$ Both themes carried through the published literature from 1996 through 2003. The literature reflected an evolution within acquisitions work centered on automation and the use of the Internet, both offering new options for communication and business practices. Budgets continued to present challenges due to the rapidly increasing costs of scholarly publications.

The last review of the acquisitions literature covered the period through $1995 .^{2}$ In order to bring the acquisitions literature reviews up to date, this paper will cover 1996 through 2003 and a second paper will cover the period 2004 through 2007. Only the key publications from 1996 through 1999 are summarized. The literature from 2000 through 2003 is reviewed in depth.

\section{Research Method}

For 1996 through 1999, the authors made very broad searches of the databases, conference proceedings, and journals on acquisition literature to identify major trends and issues for those years. Articles and abstracts were reviewed for scope and coverage of acquisitions topics. Selected publications were chosen to represent the key trends and issues of importance during this time frame. No attempt was made to review every article.

To identify the significant acquisitions literature published from 2000 through 2003 , the authors took two approaches. First, general acquisitions searches were conducted in the databases Library Literature and Information Science Abstract with Full Text and Library, Information Science, and Technology Abstracts with Full Text. Second, additional searches of these databases and selected library journals were conducted using more specific terms related to acquisitions. Citations and abstracts were reviewed for possible inclusion in the review. Searches were 
limited to scholarly journal articles, conference proceedings, and reports in English. Every attempt was made to find literature relating to any aspect of acquisitions; however, the authors concede that some works may have been overlooked. Selected articles were retrieved and reviewed in detail by both authors, who then grouped them by topics. Those papers that bridged more than one topic were placed under the topic that was most prominent. Some literature fell outside the major themes identified or was peripheral to the topics; these were excluded from the review.

\section{Summary of the Acquisitions Literature 1996 through 1999}

Automated systems development and communication via the Internet continued to be the primary forces for change in acquisitions. Lines began to blur between collection development, acquisitions, and cataloging. Ordering materials no longer occurred just within the acquisitions department and cataloging no longer occurred just within the cataloging department. Approval plans, while still traditional in many respects, took on a new look as the activity of receiving, reviewing, and accepting or returning books on approval became a virtual activity rather than a physical one. Because of the ease of communication via the Internet, vendors modified how they offered old services and opened doors to new ones.

Invariably, the availability of automation updates and new technologies resulted in change, allowing tasks to be done more effectively and more efficiently. Such changes brought new opportunities and often new responsibilities. They forced organizations to examine their purpose, processes, and structure in order to take better advantage of these opportunities.

Reorganization and change were continuing topics in the acquisitions literature. At the 1995 Feather River Institute, Cook presented a paper on reorganization at Appalachian State University. ${ }^{3}$ The Association for Library Collections and Technical Services (ALCTS) hosted an American Library Association (ALA) preconference in 1997 on changes occurring in acquisitions. ${ }^{4}$ The journal Library Acquisitions published a special issue in 1998 on reorganization in acquisitions departments. ${ }^{5}$ This issue presented articles on the merging of the acquisitions and serials departments at the University of New Mexico, decentralizing serials receipts at two branches of the University of Washington, outsourcing at Stanford, reorganizing collection development and acquisitions at the University of Dayton, acquiring electronic resources at Texas Tech by using a cross-functional team approach, and the changes in the acquisitions department at Notre Dame in the 1990s.

With reorganization, roles changed. Staff positions often were expanded and the acquisitions librarian usually assumed new responsibilities. The literature reported a decrease in the number of acquisitions librarians. Many were moved to other assignments within the library; others assumed new responsibilities such as collection development, negotiating license agreements and pricing for electronic resources, and copyright management. Diedrichs stressed that "acquisitions librarians must also be prepared to move beyond our traditional roles and cultures. Our first and foremost job is to be librarians." ${ }^{\prime 6}$ Ogburn indicated that acquisitions librarians were moving into a records and materials management phase with more time being spent on acquiring records, information, and services and less time on actually acquiring materials. ${ }^{7}$ Two key skills needed for success were negotiation and the ability to understand contracts.

Regardless of the impact of automation on organization, the budget continually commanded attention. Hoffert reported in 1998 that public libraries experienced an average increase in materials budget of 7 percent compared to $1997 .{ }^{8}$ Budgets for academic libraries also increased an average of 7 percent, but so did costs. ${ }^{9}$ Hoffert noted that during the previous five years, the costs for monographs had increased 25 percent and serial prices had increased even more. For the Association of Research Libraries (ARL), she also noted that serial unit costs rose 169 percent from 1986 to 1996. The purchase of monographs and serials decreased, which was offset by increased interlibrary loan activity and libraries forming consortia.

Budd and Craven were concerned about the impact of shrinking budgets on library resources, especially on holdings of unique titles. ${ }^{10}$ Their study demonstrated a significant decline in unique materials across all subjects. Morris and colleagues at Iowa State University performed a time-and-cost study to determine staffing costs associated with monograph acquisitions and the impact of automation on the process. ${ }^{11}$

As a result of the continuing budget squeeze, acquisition librarians continued to focus on approval plans, firm orders, and discounts to trim costs. Outsourcing was tested and viewed with varying opinions and results. Approval plans became more prevalent as a cost savings measure. The Acquisitions Librarian dedicated an issue to the topic of approval plans. ${ }^{12}$ Authors in this issue investigated the degree of overlap of titles between institutions, whether approval plans work for small libraries, the impact of approval plans on the firm order process, the impact of approval plans on the library structure and the need for active management to make them cost effective, the issues of profile construction and returns, and relationships between vendors, publishers, and libraries. An ARL study compiled by Flood showed that approval plans continued to be efficient and cost effective. ${ }^{13}$ Wilkinson and Thorson examined using a Request for Proposal as another means for acquiring serials 
or for acquiring approval plans. ${ }^{14}$ Even small details became important to cost savings. Barnes examined ways of utilizing macros to save keystrokes and reduce errors for selection, budgeting, and ordering. ${ }^{15}$

The Internet increased libraries' ability to do business with nontraditional vendors. At the 1998 Feather River Institute, Scheschy discussed the growth of online publishers and booksellers who provide alternative sources for materials. ${ }^{16}$ The use of these Internet options was particularly important for reducing costs of acquiring rush materials and out-of-print titles.

The serials crisis that began in the 1980s continued through the 1990s, although the term "serials crisis" was used less as the decade progressed. The rising cost of materials resulted in difficult choices as librarians struggled to meet users' needs with a limited budget. Librarians were faced with either trimming monograph budgets to support ever increasing serials budgets or canceling serials. The literature showed that the methods often used to determine which journals to cancel were price histories, journal usage, faculty recommendations, and alternative sources. Part of Bowling Green State University's cancellation plan reported by Brown was to use document delivery as a means of meeting users' needs for journals no longer held locally. ${ }^{17}$ Nationwide, concern was expressed about the effects of repetitive cancellations. Chrzastowski and Schmidt found that libraries' cancellation of unique journals and retention of only core collections had resulted in widespread duplication of journals nationwide. ${ }^{18}$ The increasing importance of electronic journals and their growth was the topic of a paper by Okerson, who discussed the different pricing models offered by publishers and vendors. ${ }^{19}$

The issue of licensing to access versus purchasing to own quickly emerged. Negotiation of licenses, a new skill for most librarians, often became the responsibility of the acquisition librarian as part of the ordering process. Literature during this time provided guidance on understanding, evaluating, and negotiating licenses. Yale University developed a Web site and electronic discussion list, LIBLICENSE (www.library.yale.edu/ llicense), to help librarians navigate the clauses of a vendor's license. Okerson described this initiative in a 1999 article. ${ }^{20}$ Davis explored the impact of license terms on copyrights and the need to identify and protect user rights in the licensing process. ${ }^{21}$ Kaye discussed copyright boundaries and the impact of technology on those boundaries. ${ }^{22}$ An ARL survey compiled by Soete and Davis examined how libraries organized electronic resource licensing and how associated problems were handled. ${ }^{23}$

Outsourcing and licensing moved library and vendor closer together. From a vendor's perspective, Nauman described how vendors changed their services and products to meet the evolving needs of acquisition departments and technical services as a whole. ${ }^{24}$ Alessi discussed changes made at Baker and Taylor in response to libraries' needs. ${ }^{25}$ At the 1996 ALA Annual Conference, Gammon discussed changes at the University of Akron Bierce Library with the implementation of services from Blackwell North America, which she referred to as a partnership to provide better service to the library's users. ${ }^{26}$

Allen and Hirshon examined the recent growth in collaboration by academic libraries, which was demonstrated by the growth of consortia. ${ }^{27}$ They based this growth on the concept that more can be done by working together than alone. Because of the serials crisis, rapid development of technology, and rapid growth of electronic resources, consortia offered an alternate model for the acquisition of materials. Resource sharing also gained more interest and growth. Allen and Hirshon saw this trend evolving as libraries seek alternatives to tight acquisitions budgets and the continually rising costs of electronic resources.

Government agencies have been shifting their services and information distribution to an electronic environment since the late 1980s. The Government Printing Reform Act of 1996 (HR 4280) limited what a depository library received in print. Hernon and Dugan reported that the government was expanding its fee-based online services, and shifting more costs to the libraries and users at a time when libraries and their depository collections were facing increased fiscal stringencies. ${ }^{28}$ McCraw saw the issue for libraries as how to budget for and fund access to government electronic information, and when the government failed to provide quality electronic information, how to budget for commercial databases. ${ }^{29}$ Cheverie was concerned about funding for the continued support of traditional materials, for the need to preserve an electronic copy, for the maintenance of an electronic collection, and for the organization and access to the collection. ${ }^{30}$

An important work during this period edited by Schmidt is Understanding the Business of Library Acquisitions. ${ }^{31}$ This book, with chapters written by experts in the field, takes a complete look at acquisitions from publishing to purchasing and includes chapters on ethics, management, and organizational issues.

\section{Review of Literature from 2000 through 2003}

Budgets continued to be an important topic in most of the literature from 2000 through 2003. The use of electronic interfaces between libraries and vendors for ordering and payment processing was explored in the literature as one way to control costs. Approval plans and standing orders were addressed in the literature with a focus on managing them as another means of control of costs. Libraries looked toward online booksellers as an option for acquiring in-print and out-of-print materials. 


\section{Budgeting and Financial Interfaces}

Budget constraints continued to be a significant issue for public and academic institutions in the new millennium. Clayton examined the four areas comprising a library's "bottom line" and their relationship to the parent institution's budget. ${ }^{32} \mathrm{He}$ identified three areas directly related to acquisitions: budget cycle, budget control, and budget allocation. Clayton emphasized that acquisition purchases, like operating funds, need to be spread evenly throughout the budget year to avoid an end-of-the-year surplus of funds that must be spent before fiscal year close. He advised libraries to overorder monographs to some extent because invoices may not arrive in time for posting against the current fiscal year. He recommended that libraries retain expenditure information to be able to monitor vendors and track allocations.

Integrating or linking the financial systems of the academic library's acquisitions unit and the parent institution provides an efficient mean of processing purchases. Lamborn and Smith's study examined the challenges, benefits, and process of automating the financial interface between the libraries' acquisitions systems and the institutions' accounting systems at the University of Northern Colorado and Colorado State University. ${ }^{33}$ They were able to transfer payment information directly into the university accounting system, which eliminated rekeying data, reduced errors, completed the payments to vendors faster, and freed library staff for other work. The authors discussed the evolution of automated interfaces and the issues and steps for establishing the interface and the workflow.

Another interface frequently used for transferring data is Electronic Data Interchange (EDI), a standard by which information may be exchanged electronically between businesses regardless of location. The International Committee on EDI for Serials (ICEDIS) described it as "the exchange of commercial information between computers irrespective of processing system. This is achieved by the use of standard formats that must be agreed to between trading partners for each document." ${ }^{\prime 34}$

In the last decade, libraries in the United States have been moving slowly toward full implementation of EDI. Bluh discussed the values in using EDI and the issues associated with implementing it. ${ }^{35}$ She suggested that using EDI could improve efficiency of routine operations such as ordering, claiming, and invoicing; free staff for more complex work; improve response time; reduce errors; and provide accurate and timely fiscal control. She also examined the use of EDI by libraries as a means of fast and reliable business communication with subscription agents and book jobbers. Bluh surveyed a small group of legal publishers regarding their current or planned use of EDI. She found that knowledge of and interest in EDI was minimal for most legal publishers because the majority of their customers had neither the need nor the capability of utilizing it. Agents and jobbers that served a larger universe of partners (including academic libraries, public libraries, and special libraries) were found to be interested in EDI.

Muir examined the use of EDI from a public library perspective in the United Kingdom and discussed the challenges associated with implementation. ${ }^{36}$ His investigation revealed that significant savings could be gained by eliminating manual processes. Using an online system resulted in fewer errors and improved processing times. In addition, a switch to vendor-supplied cataloging resulted in savings in staff time, which allowed staff to move into customer-service roles in the library.

Taglienti and Srivastava faced a different problem in the tracking and payment of acquisitions materials. ${ }^{37}$ Local accounting needs and the acquisitions module of the integrated library system (ILS) did not mesh, forcing the authors to develop local Microsoft Access databases to automate existing practices. Initially they developed a standing order database for automating standing order check-in and a periodical account database for serial invoicing. Later, these databases were combined and a monograph orders database was developed to form an acquisitions module.

Most libraries continued to face budget constraints from 2000 through 2003. Flowers reported on strategies to gain internal operating efficiencies at the University of North Carolina at Chapel Hill. ${ }^{38}$ In 2002, she implemented five strategies to meet budget constraints. The first was the "book year," which is the specified time frame during which funds may be encumbered for the fiscal year. The second was the use of a large approval plan that could be adjusted to meet changing budgets. The third was the use of students or temporary help during peak ordering and receiving periods. The fourth was to favor use of nonstate funds, if available. The fifth was to use the vendor's database for online selection and ordering to place orders more quickly. In addition, other operational efficiencies such as vendor evaluation, encumbrance control on foreign currency conversion, resource sharing, cancellation of print serials, use of standing orders or firm orders, less tolerance for duplicates, and more price negotiation with publishers were used.

Part of managing the budget is the allocation of funds. Dividing the acquisitions budget among the various departments is a potential source of conflict. While Clayton mentioned allocation in discussing the library's bottom line, acquisitions is often deeply involved with the process of determining how the allocation will be made. Durant described six methods for allocation of funds often used in an academic environment. ${ }^{39} \mathrm{~A}$ lump-sum budget involves a set amount of money allocated for materials that is used until all the money is spent and that uses a single account to fund all activities. The formula budget allocates dollars based on various criteria as established by the library. The line-item 
budget allocates amounts to disciplines or departments. The program budget allocation reflects library service provided to patrons, while the performance budget (or function budget) reflects the tasks that the library staff performs. The last type is the zero-based method, which is informed by projected activities and expenses as opposed to current or past services. Understanding these budgeting options is important to determining the best method to use.

Mulliner described the allocation formula used at Ohio University $(\mathrm{OU}) .^{40}$ The OU formula is applied to 70 percent of the budget and spans the academic departments. The formula includes media and format criteria. Five percent of the budget is used for interdisciplinary and area studies program and 25 percent is used for library needs such as general periodicals, reference, and special collections. This base formula is carried forward each year and updated every three years. The updated formula is applied only to increased (new) funding. Disciplines may not be funded at 100 percent of their formula levels, but over time funding will draw closer to the desired level. This method moderates the effects of any big swings in funding levels, avoids subscription cancellations due to formula-dictated decreases, and mitigates opposition against using the formula during budget decreases.

Payne of Furman University Library (FUL) discussed key lessons learned from developing a new allocation formula designed to be implemented over a two-year period. ${ }^{41}$ The impetus for the allocation change was journal price inflation. Payne stressed that the library must articulate the current system's problems, set clear goals for the reallocation process, and realize that no ideal formula exists. Budget allocation is a political process requiring persuasion and compromise. Formula development is iterative and creates winners and losers. Libraries must be ready to deal with political fallout.

Arora and Klabjan were concerned with the increase of periodical prices, the tremendous growth of scholarly research, and the limited increase in the acquisition's budget. ${ }^{42}$ Their focus was the allocation of funds from a single journal budget among several interrelated units of an academic library. Their allocation method used a mathematical model based on citations data from the Thomson Scientific ISI database. The model also could be modified to include allocations for electronic journals based on usage data from vendors for the number of times electronic journals were accessed.

Wise and Perushek proposed another mathematical model for budget allocation, which they referred to as goal programming. ${ }^{43}$ Goal programming techniques rank the goals in terms of their importance to the organization and provide a solution for conflicting or incommensurable goals. The model focuses "on minimizing the deviations between the goals themselves and what can be achieved within the given set of constraints rather than trying to maximize or minimize the objective the objective criterion directly." ${ }^{\prime 4}$

Kao, Chang, and Lin proposed another allocation model, which they referred to as "acquisition budget allocation model via data mining" or ABAMDM. ${ }^{45}$ In this model, mined circulation data informed how the budget should be distributed to the various departments. The authors believed that daily circulation data would be influenced by the use of electronic resources, complicating the allocation process. The model was tested at Kuhn Shan University of Technology and proved to be an acceptable method in determining budget allocation.

Similarly, Wu used a data mining model (DMBA) for allocating funds based on the utilization of library materials ${ }^{46}$ Wu's model extended the ABAMDM model by computerizing the process using Structured Query Language (SQL) to gain efficiency in preprocessing circulation data. The program uses that data to develop the concentration (utilization) for the different circulation categories, which is combined with statistics to derive the final weights as a basis to determine allocation.

Packer researched the impact of interdisciplinary Webbased, full text databases and bundled subscription packages on the library's existing allocation plan. ${ }^{47}$ Bundled packages, often referred to as the "Big Deal," offer a mix of electronic journal titles, some of which may have little value to the institution's teaching and research agendas. Publishers advertise that such bundled subscription packages lower the individual cost of each title. Packer argued that a bundled purchase may not be easily justified if its cost requires cancellation of other valued materials or reduces funds for some academic disciplines. The key question is how well the aggregated subscriptions support the library's curriculum and research objectives for its collection. Her study showed that "the change in 'expenditure' for subscription titles ranges from nothing at all to 221.715 percent for Health Sciences titles, followed by 58.448 percent for Sociology and 32.75 percent for Technology." ${ }^{\prime 4}$ Packer's analysis revealed that bundled packages provided a differential gain that was unintended, unplanned, and made the effects on the budget inequitable.

Albanese reported that the 2001 Library Journal Academic Library Book Buying Survey confirmed the widely held impression that libraries were shifting from print to electronic resources. ${ }^{49}$ One factor driving this shift was costeffective access to information provided by vendors' full text databases. The key factors influencing the purchase of full text aggregated databases as well as electronic journals were distance learning programs and student demand for access to online materials. The study revealed that even as material budgets increased slightly, rising inflation and increased cost of digital materials diminished the library's buying power, resulting in continued cancellation of journals. The study 
also revealed that the availability of electronic resources reduced spending for books in areas such as reference, computer science materials, and science materials.

Petrick examined the acquisitions budget of the State University of New York to determine whether the increasing purchases of electronic resources were affecting the overall acquisition of materials at the university. ${ }^{50}$ Budget data from 1994 through 2000 showed that in some cases, print materials were cancelled due to duplication of electronic journals available within an aggregated database. His findings indicated that the funds spent on electronic resources were increasing but that the increase generally was not taken from other areas.

Gherman, university librarian of Vanderbilt University, addressed two major acquisitions problems — budget allocation and storage space. ${ }^{51}$ The methodology used for budget allocation was based primarily on use statistics because the library did not have a centralized budget. This traditional method of allocation had become unreliable with the increased use and availability of electronic resources. At the same time, storage space was at a premium because the collection had filled the existing space. Given these two conditions, plans were made to build a digital library by aggressively acquiring digital products. Gherman also developed a strategy for managing the existing print-based collection. The library joined the Information Alliance with the University of Tennessee at Knoxville and the University of Kentucky, which supported resource sharing. Vanderbilt focused on reducing internal costs so that more funds could be redirected to scholarly resources. Vanderbilt also participated in a pricing experiment called PEAK (Pricing Electronic Access to Knowledge), a pilot project that provided access to all Elsevier journals, and joined the Southeastern Library Network (SOLINET) for the consortial purchase of e-books.

For school libraries, much of the acquisitions literature focused on budgets, practical applications for controlling budgets, and developing ways for schools to acquire materials on restricted budgets. Truett and Lowe studied the allocation of the school library budget in North Carolina and performed a survey of schools in western North Carolina. ${ }^{52}$ They were interested in the distribution of monies to the school media centers. The involvement of site-based management teams (SBM) or school improvement teams (SIT) in the allocation of the budget, how involved the media specialist were involved in the allocation process, and the media specialists' understanding of the budget process were influences. Funding of public schools in North Carolina is based on average daily membership (ADM) in which the enrollment is multiplied by the per-child allocation determined by the state. The suggested allocation for the media center was 60 percent of the instructional materials budget. For 2001-02, the authors calculated the allocation per stu- dent for the media center was $\$ 29$. The authors found that few media specialists knew the total school budget or what percent of the budget they received. They found that even though schools had SBMs or SITs, the principals made the final budget decisions and the final approval of purchases. Five percent of the media specialist reported a zero budget, and more than half reported $\$ 7,500$ or less thus showing inequities in the school library amounts.

The May/June 2002 issue of The Book Report contained several articles in a section titled, "Spending Smart: How to Budget and Finance" that provided practical advice about managing collections and budgets in school libraries. ${ }^{53}$ Bernstein offered suggestions on budget planning and spending priorities. ${ }^{54}$ She suggested developing a budget by using guidelines and statistics from the state education association as a starting point. This approach could also serve as a starting point for discussing budget needs with the administration. Bernstein also offered suggestions for handling teacher and student materials requests.

Baule offered steps to increase the materials budgets and observed that often the reasons for not getting needed funds are that school librarians fail to ask or their proposals are not focused on the right issues ${ }^{55}$ He pointed out that schools often have discretionary funds that can be requested and recommended that requests should focus on the budget holder's priorities. Baule also provided ten suggestions for stretching a budget.

Barringer used Microsoft Excel to manage her school library's budget, her orders, and her collection. ${ }^{56}$ She developed a template in Excel that conformed to her school district's requisition standards. Formulas entered into the template automatically updated the spreadsheet and budget. By checking the sheet, Barringer could tell what had been ordered so that duplicate orders were not placed, which books were on back order, and which requests were being held for more funds.

Using a credit card for library purchases can be an easy way to expedite purchases and save money. Buchanan requested a library charge card for purchasing materials. ${ }^{57}$ One of the main benefits was the turnaround time, often within two days, for receipt of the materials. A second benefit was the savings on shipping charges for charge card orders, which may be 8 to 10 percent of the total. Buchanan established procedures for creating a purchase order, the approval process, placing the order, and bill payment. She stressed the need for responsible use of a library charge card and the importance of maintaining good records and a good filing system.

Harbour utilized collection mapping to maintain her collection and to make budget decisions. ${ }^{58}$ Collection mapping can help media specialists make weeding decisions, show how the library collection supports the curriculum, support funding requests and plan budgets, and show where 
the monies have been spent. She detailed the process of establishing a collection map and how to use it for collections that support a specific unit. Harbour found collection mapping to be a good planning tool and, over time, to be useful to determine the quality of a collection.

\section{Approval Plans and Standing Orders}

Approval plans and standing orders continued to be a major topic in the acquisition literature, mostly from the perspective of cost. New technology enabled libraries to move from the traditional approval review shelf to an electronic approval shelf.

Flowers described the goal of acquisitions at the University of North Carolina at Chapel Hill as obtaining material quickly, cheaply, and efficiently. ${ }^{59}$ She examined how approval plans and standing orders affect the accomplishment of these goals. Depending on how standing orders and approval plans are administered, they can reduce the cost of material. Flowers determined that savings could be gained if some items on standing order were switched to an approval plan. She found predicting expenditures was difficult because publication patterns are not regular. She noted that some monographic titles can be handled more efficiently on an approval plan that is monitored and tweaked as needed.

Langendorfer and Hurst examined the options of purchasing continuations on approval plans or on standing orders ${ }^{60}$ They summarized the advantages and disadvantages of both plans using the vendor YBP. The key advantage of a standing order plan is that the vendor provides important services such as duplication control, change of status of series, quantity of stock, and discounts. An approval plan offers the flexibility to evaluate volumes and accept only what is needed, the ability to adjust the library's profile for series, and discounts. While each library should evaluate their local needs, the authors suggested that the standing order is a better choice if a complete series is desired; otherwise the approval plan offers more flexibility.

Plodinec and Schmidt evaluated approval plans and standing orders to see if they offered a possible means of controlling cost. ${ }^{61}$ The Mississippi State University (MSU) Libraries established an approval plan with Blackwell Book Services to supply books from 338 university presses. Included in this plan were seven presses that also provided standing orders. The standing order for the University Press of Mississippi was maintained; however, MSU Libraries did further research before deciding to drop the remaining six standing orders or block them from the approval plan. The authors found that costs could be reduced by 4.72 percent by using the approval plan even when taking into account shipping and handling costs. Timeliness of books received from the vendors varied. Those on standing orders arrived before those on approval 82 percent of the time. Department heads did not consider timeliness the most important factor. Twenty-nine percent of the books received on the standing orders were either excluded from the approval plan due to either profiling choices or cost limitation, or were deemed not appropriate by the vendor. MSU Libraries considered the ability to review the books on the approval plan an important advantage over the standing order process. Given this and the cost savings, MSU Libraries decided to drop the standing orders.

Bartolo, Wicks, and Ott described the process of establishing a monographic approval plan in geography, which also could be used for selection across the OhioLINK (Ohio Library and Information Network) consortium. ${ }^{62}$ Under the statewide Cooperative Collection Building Initiative, libraries could develop their own profiles for statewide use. Kent State University Libraries wrote a new monographic approval plan profile and explored the degree of interdisciplinary overlap in geography as part of their initiative. The exploratory study showed measurable interdisciplinary interests warrant further study to determine if joint acquisitions between disciplines could maximize investment and possibly have application in statewide approval plans.

Oddo demonstrated that establishing a Modern Greek approval plan was not an easy process. ${ }^{63}$ Oddo designed a plan that focused on Modern Greek history, literature and literary criticism, economics and economic theory, social conditions, and political science. His initial approach was to modify one of the existing foreign language approval plans, but he found that they could not be easily modified for Greek materials. Oddo then made inquiries directly to Greek vendors; but these vendors responded slowly or not at all, and generally had a limited in-stock offering. The best source for Modern Greek titles was colleagues traveling to Greece who would purchase books for the library or would encourage booksellers to send orders immediately. In the end, Oddo established a new approval plan covering general reference texts and individual bibliographies, history, economics, social history, language, fine arts, Greek Church history, and serials with the hope that the selected vendor will be responsive.

A frequent challenge faced by acquisition librarians is the request for material that is not yet published (NYP). The primary concern is tracking the order and publication status because they have a forthcoming effect on the budget. Bazirjian described a procedure developed by the Acquisitions Services Department at Pennsylvania State University (PSU) Libraries to efficiently handle NYP materials ${ }^{64}$ PSU Libraries made the decision to not carry over NYP materials as encumbrances from one fiscal year to another because they affected purchase capability in both the current and new fiscal years. PSU Libraries used the Sirsi Corporation software, Unicorn, as its management system for NYP orders. 
By building modified bibliographic records for NYP orders in Unicorn in advance of publication, acquisitions eliminated the need to store or track paper order requests. The system provided regular reports for the NYP titles, allowed selectors to view their requests, and allowed the acquisitions department to view a list of the NYP requests. A report, based on a pre-established review date, could be generated for the selectors to check monthly by title or subject. When the title became available, an order was placed. If a title were not yet available, a new review date was set.

Resource sharing among institutions has created a need to build group or consortial approval plans to maximize benefits. Diedrichs described the development of the OhioLINK statewide consortial approval plan. ${ }^{65}$ She discussed the concerns, the process, and the success of developing a cooperative approval plan for the purchase of monographs. The vision was to select only one vendor for the approval plan with OhioLINK signing the agreement on behalf of all libraries, eliminating the need for each individual library to do so. The expectation was that the discount would be the same or better than existing approval plan arrangements. Each individual library would retain control of its own approval file and the central system would track the number of copies ordered. The two main barriers to the project were commitment (participation was optional) and infrastructure support. Other potential barriers were turf protection, expense of loaning versus purchasing, rigidity of definition, budget issues, strained consensus, and turnover in membership. Diedrichs also discussed the process of selecting the vendor for the consortium, consortia-specific issues, and the benefits of the plan.

Armstrong and Nardini examined the possibility of a consortial approval plan for the Triangle Research Libraries Network, composed of Duke University, North Carolina Central University, North Carolina State University, and the University of North Carolina at Chapel Hill. ${ }^{66}$ For their study, acquisitions in four Library of Congress class numbers were examined over a six-month period to determine if current needs were being met by separate approval plans or if a consortial plan would be of benefit. Their study focused on determining how much overlap occurred, how titles not acquired on approval were ordered and received, the level of use based on circulation data, whether low circulating titles could be placed in working categories, possible savings if plans were coordinated, and whether titles not acquired would be valuable additions. The study revealed that savings would be realized if the approval plans were coordinated.

Worley described how the General Libraries of the University of Texas at Austin took advantage of two options offered by Blackwell's Book Services to reduce their costs. ${ }^{67}$ By using Blackwell's Preferred Edition and Paper Preferred options, the Libraries were able to reduce costs by nearly 11 percent. The General Libraries had two approval plans to obtain titles from the United Kingdom and from the United States. No discount was received for titles received under the UK plan, but titles received under the U.S. plan were discounted and frequently offered at a lower list price. By switching to the Preferred Edition option, UK titles that were also available for purchase through the U.S. office were received directly from the U.S. unit with the related discount and lower pricing. The switch to the Paper Preferred plan provided the paperback edition instead of the hardbound edition if there was a price difference of a certain amount and if it would be available within sixty days. Worley provided a detailed description of their approval plans prior to implementing the two options and the process of establishing them. He also described some of the limitations that libraries need to be aware of when using either plan.

Technology enabled vendors to offer new services or to offer old services in a new way, such as the virtual approval plan. Pugh noted that selectors have commented that they do not have sufficient time to look at approval shelves. ${ }^{68} \mathrm{~A}$ virtual approval plan could improve this situation by eliminating the time constraints. However, a virtual approval plan could increase the number of titles for online review. Pugh suggested using a virtual approval plan as a supplement to the normal process for the selection of difficult titles.

Clendenning's article discussed the changing roles of collection development and acquisitions at the University of Virginia Libraries (UVL) ${ }^{69}$ Looking for a better way to meet its primary goal of responding quickly to users' needs, UVL looked for an improved method to expedite delivery of approval plan books. One solution was for YBP to supply approval notification slips in electronic form through their Global Online Bibliographic Information (GOBI) order database. Through GOBI, the selectors could do both the selecting and ordering functions. This reduced the time delay of handling paper slips. In some situations, the stock would be depleted by the time the order was placed, and it would be placed on back order. Clendenning reported that with the change to the online approval system, delivery times were dramatically reduced, books arrived within two weeks of the invoice date, and materials arrived shelf-ready.

With the rising journal costs, Galbraith of Washington State University's Owen Science and Engineering Library wanted to scale back or eliminate the approval book plan as a way to reduce costs. ${ }^{70}$ Galbraith's plan was to utilize Collection Manager, Blackwell's Web-based approval plan. Selectors received training from Blackwell on Collection Manager and eNotes, and Blackwell addressed their concerns and procedures. After a year and a half of evaluation, the library switched to ordering via Collection Manager and stop using approval books. Galbraith found that they were more successful making selections by using Collection Manager, eNotes, table of contents, and book jacket infor- 
mation than by having the vendor select and send titles on approval.

Flowers and Perry examined decentralizing ordering and moving to online selection and ordering, which they called vendor-assisted e-selection. ${ }^{71}$ Factors influencing the move toward e-selection and online ordering were decline in library staffing, desire to meet user's expectation of delivery times, and development of expanded services and online tools by vendors. The authors described the changes made in the Academic Affairs Library at the University of North Carolina Chapel Hill and at the University of Chicago Libraries to implement an online selection and ordering process. Some of the trade-offs in implementing the process were the potential increase of duplicate items, a more complex process that tied the library more closely with one vendor, and the time and training required to establish the e-selection process.

McColl and colleagues of the Tri-College Consortium wanted to reduce material costs and staff time. ${ }^{72}$ The Consortium (Bryn Mawr, Haverford, and Swarthmore colleges) share an online catalog and library materials. Because of their close physical proximity, Bryn Mawr and Haverford shared a shelf approval plan while Swarthmore had its own shelf approval plan. By using a virtual approval shelf, the three colleges shared a single approval plan and reduced duplication and costs. In addition, they saved on travel time for selectors by eliminating the need to review the books in person. They also switched to a shelf-ready service, which reduced the processing time and shipped the books directly to the receiving library. While this change clearly reduced acquisition's costs and time, the authors were concerned about the added online review time spent by the bibliographers. They hoped that the approval plan profile could be adjusted to eliminate such extra work in all but a few subject areas.

Vendors have developed electronic products to replace most of the print tools used for finding, evaluating, and ordering resources. Wiegand evaluated several cost-effective and customizable electronic products available for use in the acquisitions process at small libraries. ${ }^{73}$ Wiegand reviewed ChoiceReviews Online, Baker and Taylor's Title Source II, Faxon's kLibrary, jake, Scout Report, Serials Update Service, and Publist.com for their use in ordering monographs and serials.

Public libraries also were shifting to electronic products and moving toward online purchasing. With the prospect of adding a new branch library, Hale needed to find a more efficient method of ordering and tracking materials for North Las Vegas Library District. ${ }^{74}$ Their ordering process was manual and lacked an efficient means of tracking orders, often resulting in duplicate titles being ordered. With the implementation of Baker and Taylor's Title Source II (TSII), the library district could download bibliographic records into the local catalog and the librarians could easily search the TSII materials for collection development purposes and to review bibliographic information. TSII allowed customers to leave orders on the system, making it easy for librarians to see if a book has been ordered previously.

One very essential book that covers all aspects of acquisitions and could fit under every heading in this review is The Complete Guide to Acquisitions Management by Wilkinson and Lewis. ${ }^{75}$ Some of the topics discussed are the acquisition of different material formats, the organization of acquisitions departments, the acquisitions systems, vendor selection, the publishing industry, outsourcing, and ethics. It is essential reading for novices in acquisitions and a resource for others in acquisitions and librarianship in general.

\section{Electronic Resources}

Since the inception of electronic journals, their management has been a challenge. Their acquisition process does [not?] fit well with existing procedures for managing print materials. Acquisitions departments have struggled with integrating them into existing workflows.

Loghry and Shannon of the University of Nevada at Reno library worked as part of a taskforce to develop a workflow for managing electronic journals. ${ }^{76}$ The result was the development of two Electronic Products Work Forms (EPWF). The first form, EPWF-I, contained selection and acquisition information and the subject specialists' recommendations. The second form, EPWF-II, tracked the steps in the approval and purchase process, including creation of license files, ordering, and establishing service once the vendor has turned on access. By utilizing these forms, the library was able to document the increase in workload and adjust staffing and structure changes.

Duranceau and Hepfer surveyed libraries about staffing needs for managing electronic resources ${ }^{77}$ From the survey responses, they found that staff support at least doubled and electronic collections grew at least ten times larger during the same period. Six areas were consistently reported as understaffed: licensing, cataloging, non-OPAC record management, access trouble-shooting, site monitoring for content changes, and setting up and maintaining links to electronic journals and Internet-accessed databases. They also found that while libraries consistently added staff hours to support electronic resources, they often did so by distributing the work to existing staff rather than hiring additional staff. At Massachusetts' Institute of Technology and the University of Buffalo Libraries, the authors found that few of the tasks involved in managing e-resources were routine; many required a broad knowledge of library systems and networks, as well as product details. While the research did not recommend whether support should be centralized 
or not, it did confirm that more staff is needed to support electronic collections.

Goldberg and McAdam examined the University of California at Irvine Libraries' Internet Processing Working Group, a collaborative approach for selecting, acquiring, and processing electronic resources. ${ }^{78}$ The group drafted requirements and guidelines for processing electronic resources in a collaborative approach with members from collection development, acquisitions, cataloging, reference, and systems. They also developed an online Electronic Resources Order/Processing Form for bibliographers to provide ordering information. A technical services coordinator, who later became the electronic resources acquisitions librarian, was responsible for identifying pricing of electronic resources and access requirements, licensing, and creating bibliographic records with orders attached.

Jasper of the Houston Academy of Medicine at Texas Medical Center (HAM-TMC) also discussed a collaborative approach to managing electronic resources with a focus on providing and maintaining access. ${ }^{79}$ The assistant director for collections played a large role in the licensing and managing of the electronic resources. At HAM-TMC the serials librarian handled subscription inquiries and payment.

Ball examined the purchasing of electronic resources by six public library consortia and five individual libraries in England. ${ }^{80}$ Data was gathered from surveys, interviews, proxy server hits, and service providers used for reviewing subscription renewals. Findings indicated that electronic resources are very expensive and that consortial negotiations often do not result in any price advantage. The trend was toward the purchasing of traditional materials. CD-ROM was the main digital medium and electronic resources were not integrated into the catalog with traditional materials. Because of the complexity of licensing for electronic resources, the preference was for a single national license for public libraries. Also, consortia and individual libraries saw a need for a national approach for electronic resources procurement.

The licensing of an electronic resource is often complex and often requires negotiation. Alford examined licensing through historical and practical perspectives. ${ }^{81}$ His discussion of negotiating points provided clear explanation of terms and arguments for negotiating changes. Miller's article focused on the introduction of licenses and four important areas: services clause, authorized users, licensee clause, and reasonable effort. ${ }^{82}$ She provided examples of each clause, different interpretations of the clauses, and a library solution for each interpretation. Richards examined the impact of licensing on copyright and the potential impact on licensees waiving their rights and on fair use. ${ }^{83}$ Blosser discussed how vendors could assist library customers with licensing and registration information. ${ }^{84}$ He viewed the vendors as middlemen, who could work with publishers to standardize the format and language of licenses. Urquhart examined the issues associated with developing a framework for purchasing and licensing electronic resources within a consortium as a form of outsourcing. ${ }^{85}$

For a report commissioned by the Digital Library Federation, Jewell examined how research libraries acquired commercial online materials. ${ }^{86}$ He covered ten key issues encountered in the acquisitions process beginning with economics and selection. Other topics addressed were licensing issues, user support, usage information, and evaluation. Jewell's report includes suggested practices for each area discussed.

Hawkins looked at the development of trends for electronic books (e-books) in the book industry. ${ }^{87} \mathrm{He}$ also discussed issues associated with the purchase of e-books and the special equipment that libraries may need for users to read them.

\section{Booksellers and Vendors}

Kruse and Holtzman examined the usefulness of online booksellers and the barriers associated with purchasing from them.$^{88}$ Local purchasing regulations and institutional auditing requirements are potential obstacles to online purchasing. Problems may occur if a signed purchase order is required or if the seller fails to include the purchase order number on the invoice. Competitive bidding is sometimes required for expensive purchases. Online booksellers often require purchases be made with a credit card. Frequent use of credit cards in acquisitions may require a procedure for tracking purchases and balancing statements. Online booksellers are geared to serve the needs of an individual, not the needs of a library. The library may not have an interface that works directly with an online vendor, which may require entering the same data into the bookseller's system and into the library system. The library could also be faced with varying shipping costs, rather than a flat fee as negotiated with most traditional book dealers. Some online booksellers offer discounts, but the discounts are normally not as high and may not offset shipping charges. While most online booksellers can handle books in print, they may have varying difficulty accepting order for prepublications, back orders, and out of stock materials. Kruse and Holtzman pointed out that the use of programs called shopping bots, which search the Internet for pricing information and may identify a source offering an expensive item at a lower price. The Web has increased accessibility of out-of-print dealers. Similarly, the Web has helped libraries find new sources for foreign titles. The Web has also aided in finding replacement copies and titles a publisher reports to be out of stock and in obtaining rush items and textbooks.

Gray of Marshall University and Brantz of Colorado Christian University (CCU) utilized discounted wholesalers 
for the purchase of print materials on two projects as a way to supplement their collections on a limited budget. ${ }^{89}$ Gray used Green Valley Book Fair, which offered a selection of 500,000 titles. Green Valley agreed to search Marshall's cata$\log$ for duplicates before the final purchase. Any duplicates missed could be returned. Some drawbacks were the selection availability, the need for an itemized invoice that listed the titles, and the cost of travel and lodging. On the positive side were the great savings and the opportunity to personally examine and select books for the library.

Brantz used local book superstores, primarily Barnes and Noble and Tattered Cover, for his project. ${ }^{90}$ As with Marshall, a process was developed to determine duplicate titles. Faculty could select materials in person at the bookstore and leave them at the sales desk for later acquisition. Because faculty could build their collection for their courses, the process resulted in adding books directly useful to the students, providing subject expertise in areas where the staff might be lacking, and building a strong institutional relationship between the faculty and the library, which has increased the support of the library.

To meet faculty's requests for quick delivery time of ordered materials, Flinchbaugh tested the use of online book vendors ${ }^{91}$ Eleven online book vendors were evaluated on availability, fill time, and cost. Six of the eleven were considered acceptable. Rush orders were filled in less than ten days and the cost per volume decreased. Flinchbaugh also implemented several organizational and procedural changes for ordering from online book vendors and for service improvement.

Allen and Miller performed a price comparison of books purchased through a traditional vendor and an online bookseller to see which was cheaper. ${ }^{92}$ The authors selected titles consisting of trade and scholarly materials varying in subject and bindings. As each title was considered for purchase, pricing data was collected from the vendor and online bookseller the same day. Only eight of the tiles on the list were available from the online bookseller at a lower price than from the vendor. Ordering from the traditional vendor resulted in a savings of $\$ 273.86$ over the online bookseller.

Kellerman described a process used at Pennsylvania State University Libraries to provide out-of-print titles that are difficult to find. ${ }^{93}$ Because publishers warehouse less material than they once did, books may become out of print quickly. Few publishers offer print-on-demand books. Current technology can produce a copy within a few days, eliminating the need to wait months for a volume. In some situations, Kellerman proposed that the University Libraries create a digitized copy of the book if it could be obtained through interlibrary loan. She found per page costs ranged from $\$ .13$ to $\$ .39$ for copyright royalties, staff time, paper, phone calls, and so on. Kellerman saw this as a viable option for libraries until vendors are able to provide service competitively.
Tonkery discussed publisher and corporate mergers and acquisitions (M\&A) from a vendor point of view. ${ }^{94}$ He noted that companies see M\&A as an "opportunity to expand the market share, gain access to technology or content, increase the product line, and increase the value of the combined companies for both sets of stockholders. Often there is an opportunity to reduce costs by reducing corporate overhead. ${ }^{" 95}$ Changes in information technology and publishing had a great effect on M\&A in the subscription agencies. Tonkery reported that between 1991 and 2001, subscription agencies dropped in number from one hundred to fewer than ten. Antitrust legislation and regulations provide a means of monitoring areas that are dominated by a few publishers such as STM (scientific, technical, and medical), legal, and tax publishing. Tonkery noted that because pricing patterns are perceived as monopolistic in the STM area, the marketplace is looking for other alternatives.

Stanley looked at M\&A from a librarian's perspective as mergers proliferated and reduced supplier choices. ${ }^{96}$ She noted that libraries need to understand that publishers and subscription agencies are businesses and thrive by showing a profit and growth, creating a market share, and responding to changing markets. She suggested that libraries check the financial stability of a newly merged company, not overlook any new services gained, and examine bottom line costs and services in determining if the company meets the library's needs. Stanley suggested that vendors remember the money and time invested in a business relationship between a library and a vendor when considering a merger. Consulting libraries before the final merger could resolve issues before they affect the library customers. She also suggested that vendors provide financial statements and information on services that will be changed.

Edelman and Holley's book, Marketing to Libraries for the New Millennium, is an essential source for understanding the marketplace. ${ }^{97}$ The book is based on a one-day meeting sponsored by the Joint Committee of the Association of American Publishers and the ALCTS. Publishers, vendors, and librarians discussed the results of a survey of library marketing practices and trends. The book covers changes and needs in the marketplace, the finding and selecting of books using the Internet, and how librarians determined from whom they would purchase materials. The book covers the complexities associated with the acquisitions of materials.

\section{Reorganization and Changes in Workflow}

Fowler and Arcand evaluated time and cost studies for monographs acquisitions at Iowa State University (ISU) Libraries between 1994-95 and 2000-01. ${ }^{98}$ The goal of their research was to increase the organization's effectiveness due to the use of advanced technology. One key result was the consolidation from multiple approval plan vendors 
to a single approval vendor. The authors explained that "the streamlining effect of the library's reliance on one vendor approval plan, as opposed to a number of smaller ones, meant that the library was able to identify and fill gaps in its collection." ${ }^{\text {"99 }}$ A related improvement was implementing PromptCat to receive records for materials ordered on approval. ISU Libraries also merged the serials and monographs acquisitions departments and automated all ordering via the Horizon ILS. These changes allowed ISU Libraries to downsize staffing through attrition and reclassify other positions with greater responsibilities to higher levels. Over several years, they saw reductions in hours and costs as these changes and technological improvements were implemented. The revamped organizational structure and workflows resulted in greater efficiencies, time and cost reductions, and staff improvements.

Branton and Englert faced a perception of inefficiencies due to a lag-time problem between the receipt of orders and the availability of the items at the University of Southern Mississippi (USM) Libraries. ${ }^{100}$ Also, due to a budget crisis, the USM Libraries were mandated to reduce and flatten the technical services unit organizational structure in a matter of days. The acquisitions and cataloging functions were merged into a new department under a single department head. A cataloging-at-point-of-order team handled all tasks from point of order to receipt of materials. Ninety percent of the print materials ordered could be handled by this new process with little change to the bibliographic record, resulting in faster delivery of new materials to the user. When duplicate and repetitive tasks were addressed and manual procedures were eliminated, USM Libraries were able to reduce the time between ordering and receiving by six to eight weeks.

Maurer and Hurst provided a detailed description of Kansas State University's (KSU) new workflow and the integration of automated technology to handle routine work and reduce costs. ${ }^{101}$ When KSU Libraries and Media Services changed vendors to YBP for their approval and firm orders, KSU also shifted their outsourced monograph cataloging from OCLC TechPro to OCLC PromptCat. With the integration of YBP and PromptCat into the workflow, KSU eliminated pre-order searching for duplicates, the transfer of records into the Innovative Interface Inc. (III) system prior to ordering, and the keying of order records from YBP, and also gained electronic invoicing from YBP. As a result of implementing these new processes, KSU was able to reduce their cost per bibliographic record by $\$ 4.96$.

Greever of the Kenyon College Library faced a similar experience when the library implemented YBP's online service, GOBI. ${ }^{102}$ Kenyon had a slip approval plan with YBP, but did not receive books on approval. With GOBI2, faculty and liaisons could select and approve orders and acquisitions staff could complete the process. As a result, acquisitions staff did less keying and less OCLC searching, bringing them closer to one-stop shopping. Additional gains were made when the Kenyon library implemented PromptCat, through which the cataloging records matched to and overlaid the YBP brief records in the local catalog.

Marshall and Tellman described the reorganization of technical services staff when the University of Arizona (UA) Library downsized and the professional positions were transferred to public services. ${ }^{103}$ The basis for the reorganization was primarily economic, but supported UA Library's mission of placing more librarians in public services. Several new plans were implemented by UA Libraries to process incoming materials under this new staffing scenario. One decision was to receive books on approval plans, preprocessed, shelf-ready, and with an appropriate bibliographic record for the catalog. Another decision was to use cataloging copy for materials received from other vendors and foreign approval plans when possible. Because a backlog was not considered acceptable, a "frontlog" was created for materials for which no records could be found. The frontlog is a public book stack area consisting of partially processed materials. The frontlog allows users to check out materials waiting for complete processing. After one year, items on frontlog for which no records are available are sent for cataloging at OCLC TechPro. The authors found that in a within a year, 898 books were retrieved from the frontlog; of that group, only 3 percent did not have records and were sent to TechPro.

Bazirjian discussed the team structure implemented at the Pennsylvania State University Libraries and the actions taken as a result of a team assessment survey. ${ }^{104}$ With the reorganization to a team structure, one librarian headed the Acquisitions Services unit and the number of functional areas was reduced to three teams: approval/ gifts, firm orders, and commonwealth services. Serials and Preservation were removed from Acquisitions Services. Teams were self-directed, and each month one staff member handled the team functions on a rotational basis. A team assessment survey was designed to determine strengths and needs of the teams; the survey results showed that the team structures should be maintained and enhanced with clearer definitions of team roles and a department head in human resources. The greatest areas for improvement were poor performance and disciplinary issues, lack of informal rewards and recognition of accomplishments, and need for accountability of assignments, performance standards, and an annual performance review process. Bazirjian stressed the importance of taking action on items from the survey.

\section{Collection Development and Interlibrary Loan}

A daily challenge for collection managers is finding ways to maintain and grow a collection within budget constraints. While all collection managers face this challenge to varying 
degrees, the sciences and engineering fields present unique situations.

A new model for adding materials to a collection consists of collaboration between collection development, acquisitions, and interlibrary loan units. Ward and colleagues examined two models for on-demand collection development that use acquisition funds for the purchase of books requested by patrons through interlibrary loan (ILL). ${ }^{105}$ The University of Wisconsin-Madison Libraries limited purchases to the subject areas housed in the General Library System, the current year plus three prior years, to monographs or proceedings, a maximum cost of $\$ 250$, potentially high use items, and foreign language and imprint titles. Requests that could not be filled through ILL were reviewed as candidates for on-demand purchase and rush processing. Primarily online providers were used for English language titles depending on the discount and shipping cost. For foreign purchases, traditional vendors were consulted. A credit card was used when possible to facilitate payment and delivery. During the two years studied, 135 titles were purchased at an average cost of $\$ 36.86$ per book including shipping, and were processed and cataloged for an average patron pickup time of eight days. The materials circulated an average of 3.5 times each with 73 percent circulating two or more times.

Purdue University Libraries' (PUL) pilot for on-demand books was similar to the one at UW-Madison. ${ }^{106}$ The main difference was that PUL sent the books to patrons before being cataloged. Purchases were based on ILL requests for recently published titles that appeared appropriate for inclusion in the local collection. Purchasing criteria were scholarly works in English, published within the past five years, available for shipment within one week, limited to a maximum cost of $\$ 150$, and available from Amazon. Once a purchase was approved, a screen print from Amazon was sent to the acquisitions unit for ordering; the titles also were entered into the ILL management system. During thirty months, 1,943 books were purchased at an average cost of $\$ 37.50$, including shipping. Fifty-seven percent of the books circulated at least once after being cataloged while only 31 percent of books acquired through the regular process circulated once. Bibliographers reviewed about half of the ondemand books and indicated that 80 to 99 percent of them were appropriate for the library collection.

Allen tested a similar plan at the Thomas Crane Public Library (TCPL) in Quincy Massachusetts, where an expedited purchasing model was utilized to fill ILL requests by purchasing titles that were subsequently added to the collection. ${ }^{107}$ In the TCPL model, the ILL librarian considered purchases on a case-by-case basis for problematic titles. Selection was based on availability, price, subject matter, and suitability for the collection. Titles were minimally processed and circulated to the patron first. They would be considered for addition to the collection when returned.
Seventy-nine percent of the items were received in fourteen days or less at an average cost of $\$ 17$, which included shipping. In 2001-02, 84 percent of the items circulated an average of three times; in the previous two years, 95 percent circulated an average of eight times per item and 30 percent circulated more than ten times.

Truck described the situation of the Public Library of Des Moines (PLDM) where the budget had not been increased in ten years and the weeding of the collections had been ignored. ${ }^{108}$ The project included determining the collection size for each library branch, choosing a median collection age, and calculating the needed budget based on the average cost per item in a material type. The desired collection size was set at 500,000 items with a medium age of five years. Truck chose median age over average because the "older important titles that are retained in the collection will not influence or drag down the overall age measurement of the collection." ${ }^{109}$ Later the median age was adjusted by using the date added to the collection instead of its copyright date. This allowed for heavily used classic titles that are replaced frequently to be considered new items. Under the collection plan, 10 percent of the collection was to be replaced every five years, which made calculating the budget simple by multiplying that figure by the average cost per item. To allocate the funds by media type and among the branches, a collection management team was formed. As a result of implementing the collection development plan, Truck was able to triple the budget, decrease collection size, and increase the availability of popular collections.

\section{Conclusion}

The acquisitions literature from 2000 to 2003 provides a significant example of the impact of new communication technologies on library operations. Acquisitions work was reviewed, redesigned, and restructured to take advantage of the dramatic power of Internet resources and capabilities. The literature of this period reveals how acquisitions staff embraced these opportunities and developed their units into significantly more efficient operations.

\section{References and Notes}

1. Karen A. Schmidt, "Acquisitions," New Trends in Technical Services: Trends and Sources (1993-1995) (Chicago: ALA, 1997), 28-45.

2. Ibid

3. Eleanor I. Cook, "Reorganization Revisited; Or, Is Acquisitions an Endangered Species?" Library Acquisitions: Practice d Theory 20, no.1 (1996): 77-84.

4. See various conference reports, e.g., Christina Easton, "Business of Acquisitions: Rethinking and Transforming Acquisitions: An ALCTS Preconference,"Library Acquisitions: Practice \& Theory 21, no. 4 (1997): 461-73. 
5. Mary Page, ed., "Special Issue on Reorganization in Acquisitions Departments," Library Acquisitions 22, no. 3 (1998): 257-58.

6. Carol Pitts Diedrichs, "Acquisitions: So What and Where? Perspective 1," The Journal of Academic Librarianship 24, no. 1 (Jan. 1998): 75.

7. Joyce L. Ogburn, "Acquisitions: So What and Where? Perspective 2," The Journal of Academic Librarianship 24, no. 1 (Jan. 1998): 76.

8. Barbara Hoffert, "Book Report: What Public Libraries Buy and How Much They Spend," Library Journal 123, no. 3 (Feb. 15, 1998): 106-10.

9. Barbara Hoffert, "Book Report, Part 2: What Academic Libraries Buy and How Much They Spend," Library Journal 123, no. 14 (Sept. 1, 1998): 144-46.

10. John M. Budd and Catherine K. Craven, "Academic Library Monographic Acquisitions: Selection of Choice's Outstanding Academic Books," Library Collections, Acquisitions, \& Technical Services 23, no. 1 (1999): 15-26.

11. Dilys E. Morris, Pamela Rebarcak, and Gordon Rowley, "Monographs Acquisitions: Staffing Costs and the Impact of Automation," Library Resources \& Technical Services 40, no. 4 (1996): 301-17.

12. Acquisitions Librarian 16, no. 1 (1996).

13. Susan Flood, comp., Evolution \& Status of Approval Plans: A SPEC Kit, SPEC Kit 221 (Washington, D.C.: Association of Research Libraries, Office of Management Services, 1997).

14. Frances C. Wilkinson and Connie Capers Thorson, The RFP Process: Effective Management of the Acquisition of Library Materials (Englewood, Colo.: Libraries Unlimited, Inc., 1998).

15. Marilyn E. Barnes, "Managing with Technology: Automating Budgeting from Acquisitions," The Bottom Line 10, no. 2 (1997): 65-73.

16. Virginia M. Scheschy, "Publishers on the Web: From Addison to Ziff," Library Collections, Acquisitions, \& Technical Services 23, no. 1 (1999): 73-78.

17. Linda A. Brown, "Balancing Information Needs with Serials Value and Costs," Against the Grain 9, no. 2 (Apr. 1997): 22, $24,26,28$.

18. Tina E. Chrzastowski and Karen A. Schmidt, "The Serials Cancellation Crisis: National Trends in Academic Library Serial Collections," Library Acquisitions: Practice \& Theory 21, no. 4 (1997): 431-43.

19. Ann Okerson, "Are We There Yet?: Online E-Resources Ten Years After," Library Trends 48, no. 4 (Spring 2000): 671-93.

20. Ann Okerson, "The LIBLICENSE Project and How It Grows," D-Lib Magazine 5, no. 9 (Sept. 1999), www.dlib.org/ dlib/september99/okerson/09okerson.html (accessed Sept. 26, 2007).

21. Trisha Davis, "License Agreements in Lieu of Copyright: Are We Signing Away Our Rights?" Library Acquisitions: Practice \& Theory 21, no. 1 (1997): 19-27.

22. Laurie Kaye, "Owning and Licensing Content: Key Legal Issues in the Electronic Environment," Journal of Information Sciences 25, no. 1 (1999): 7-14.

23. George J. Soete and Trisha Davis, Managing the Licensing of Electronic Products, SPEC Kit no. 248 (Washington, D.C.:
Association of Research Libraries, Office of Leadership and Management Services, 1999).

24. Matthew Nauman, "Vendors and Academic Libraries: Development and Change," The Bottom Line 10, no. 4 (1997): 165-68.

25. Dana L. Alessi, "Raising the Bar: Book Vendors and the New Realities of Service," Journal of Library Administration 28, no. 2 (1999): 25-40.

26. Julia A. Gammon, "Partnering with Vendors for Increased Productivity in Technical Services or, Bleeding Edge Technology," Library Acquisitions: Practice \& Theory 21, no. 2 (1997): 229-35.

27. Barbara McFadden Allen and Arnold Hirshon, "Hanging Together to Avoid Hanging Separately: Opportunities for Academic Libraries and Consortia," Information Technology and Libraries 17, no. 1 (March 1998): 36-44.

28. Peter Hernon and Robert E. Dugan, "The Depository Library Program in the 21st Century: The Issue is One of Which Services to Offer," The Journal of Academic Librarianship 23, no. 3 (May 1997): 224-25.

29. J. B. McCraw, "Byte the Bullet: Unfunded Mandate for US Government Information in Electronic Formats," The Bottom Line 12, no. 3 (Sept. 1999): 108-12.

30. Joan Cheverie, "Federal Information in the Networked Environment: A Perspective from the Coalition for Networked Information," Government Information Quarterly 16, no. 3 (1999): 261-75.

31. Karen A. Schmidt, ed., Understanding the Business of Library Acquisitions (Chicago: ALA, 1999).

32. Peter Clayton, "Managing the Acquisitions Budget: A Practical Perspective," The Bottom Line 14, no. 3 (2001): 145-51.

33. Joan G. Lamborn and Patricia A. Smith, "Institutional Ties: Developing an Interface between a Library Acquisitions System and a Parent Institution Accounting System," Library Collections, Acquisitions, \& Technical Services 25, no. 3 (Fall 2001): 247-61.

34. International Committee on EDI for Serials, What is EDI? (2006), www.icedis.org/edi.html (accessed Sept. 3, 2007).

35. Pamela Bluh, "Perception Versus Reality: Electronic Data Interchange in the Law Library Environment," Law Library Journal 93, no. 2 (Spring 2001): 269-84.

36. Lindsey Muir, "Why Should Public Libraries Use Electronic Data Interchange?” New Library World 101, no. 1157 (2000): 222-27.

37. Paolina Taglienti and Sandhya D. Srivastava, "Reinventing the Wheel: The Microsoft Access Alternative," Against the Grain 14, no. 2 (April 2002): 20-26.

38. Janet L. Flowers, "Operational Efficiencies in Acquisitions to Minimize the Impact of Budget Cuts upon Library Materials Budgets," The Bottom Line 16, no. 2 (2003): 69-75.

39. Joyce M. Durant, "For Love of Money: Budget Allocations," in Charleston Conference Proceedings: Is Bigger Better?, ed. Rosann Bazirjian and Vicky Speck (Charleston, S.C.: Against the Grain Press, 2000), 211-15.

40. Kent Mulliner, "Why Who Gets What When: Ohio University's Acquisitions Allocation Formula after 20 Years," in Charleston Conference Proceedings: Is Bigger Better? ed. Rosann Bazirjian and Vicky Speck (Charleston, S.C.: Against the 
Grain Press, 2000), 216-21.

41. John K. Payne, "For Love of Money: Library Budget Allocation," in Charleston Conference Proceedings: Is Bigger Better? ed. Rosann Bazirjian and Vicky Speck (Charleston, S.C.: Against the Grain Press, 2000), 222-24.

42. Anish Arora and Diego Klabjan, "A Model for Budget Allocation in Multi-Unit Libraries," Library Collections, Acquisitions, \& Technical Services 26, no. 4 (Winter 2002): 423-38.

43. Kenneth Wise and D. E. Perushek, "Goal Programming as a Solution Technique for the Acquisitions Allocation Problem," Library \& Information Science Research 22, no. 2 (2000): $165-83$.

44. Ibid.,167.

45. S. C. Kao, H. C. Chang, and C. H. Lin, "Decision Support for the Academic Library Acquisition Budget Allocation via Circulation Database Mining," Information Processing \& Management 39, no. 1 (Jan. 2003): 133.

46. Chien-Hsing Wu, "Data Mining Applied to Material Acquisition Budget Allocation for Libraries: Design and Development," Expert Systems with Applications 25, no. 3 (2003): 401-11.

47. Donna Packer, "Acquisitions Allocations: Fairness, Equity and Bundled Pricing," portal: Libraries and the Academy 1, no. 3 (July 2001): 209-24.

48. Ibid., 218.

49. Andrew Richard Albanese, "Moving from Books to Bytes," Library Journal 126, no. 14 (Sept. 2001): 52-54.

50. Joseph Petrick, "Electronic Resources and Acquisitions Budgets: SUNY statistics, 1994-2000," Collection Building 21, no. 3 (2002): 123-33.

51. Paul M. Gherman, "Found Money: Trading Infrastructure for Information," Journal of Library Administration 31, no. 2 (2000): 49-62.

52. Carol Truett and Karen Lowe, "The School Library Budget: A Study in Power and Politics of Selected North Carolina School Library Budgets," North Carolina Libraries Online, 61, no. 1 (Spring 2003): 13-29, www.nclaonline.org/NCL (accessed Jan. 19, 2008).

53. "Spending Smart: How to Budget and Finance," The Book Report 21, no. 1 (May/June 2002): 6-24.

54. Allison Bernstein, "Making Sense of Your Budget Dollars," The Book Report 21, no. 1 (May/June 2002): 6-7.

55. Steve Baule, "Success with Budget Proposals," The Book Report 21, no. 1 (May/June 2002): 8-10.

56. Crystal Barringer, "Using Microsoft ${ }^{\circledR}$ Excel to Plan and Budget in Your School Library," The Book Report 21, no. 1 (May/June 2002): 16-18.

57. Peggy Buchanan, "Charging Ahead," The Book Report 21, no. 1 (May/June 2002): 20-21.

58. Denise Harbour, "Collection Mapping," The Book Report 20, no. 5 (Mar./Apr. 2002): 6-10.

59. Janet L. Flowers, "Extension of Purchasing Power through Use of Approval Plans Rather than Standing Orders for Monograph-Like Materials," The Bottom Line 15, no. 3 (2002): 135-39.

60. Jeanne M. Langendorfer and Michele L. Hurst, “Comparison Shopping: Purchasing Continuations as Standing Orders or on
Approval," Library Collections, Acquisitions, and Technical Services 27, no. 2 (Summer 2003): 169-72.

61. Louise Plodinec and June Breland Schmidt, "Which Worked Better for Mississippi State: Standing Orders or an Approval Plan?" Library Collections, Acquisitions, \& Technical Services 26, no. 4 (Winter 2002): 439-48.

62. Laura M. Bartolo, Don A. Wicks, and Valerie A. Ott, "Border Crossing in a Research University: An Exploratory Analysis of a Library Approval Plan Profile of Geography," Collection Management 27, no. 3/4 (2002): 29-44.

63. Anthony J. Oddo, "Creating a Greek Approval Plan at Yale," Against the Grain 12, no. 4 (Sept. 2000): 42-44.

64. Rosann Bazirjian, "Tracking Not Yet Published Material: Using the Bibliographic Record the Smart Way," Against the Grain 15, no. 1 (Feb. 2003): 42, 44, 46-47.

65. Carol Pitts Diedrichs, "Designing and Implementing a Consortial Approval Plan: The OhioLINK Experience," Collection Management 24, no. 1/2 (2000): 45-55.

66. Kim Armstrong and Bob Nardini, "Making the Common Uncommon?: Examining Consortial Approval Plan Cooperation," Collection Management 25, no. 3 (2001): 87-105.

67. Glen Worley, "Squeezing the Most out of the Approval Plan Budget: The University of Texas at Austin and Blackwell's Book Services Preferred Edition and Paper Preferred Options," Against the Grain 12, no. 3 (June 2000): 16-26.

68. Stephen Pugh, "The Decline of the Poultry Selector: Thoughts on the Virtual Approval Plan," Against the Grain 14, no. 3 (June 2002): 32-34.

69. Lynda Fuller Clendenning, "Crossing the Great Divide between Acquisitions and Collections: Selectors Order Online," Against the Grain 12, no. 6 (Dec. 2000/Jan. 2001): 85-88

70. Betty Galbraith, "Evaluating Blackwell's Collection Manager as a Replacement for Approval Books," Science \& Technology Libraries 20, no. 4 (2001): 5-11.

71. Janet L. Flowers and Scott Perry, "Vendor-Assisted E-selection and Online Ordering: Optimal Conditions," Library Collections, Acquisitions, \& Technical Services 26, no. 4 (2002): 395-407.

72. Amy McColl et al., "The Virtual Approval Shelf: A Look Towards the Future?" Against the Grain 14, no. 3 (June 2002): 28-32.

73. Sue Wiegand, "Incorporating Electronic Products into the Acquisitions Workflow in a Small College Library," Library Collections, Acquisitions, \& Technical Services 26, no. 4 (2002): 363-66.

74. Marylou Hale, "How Title Source II Changed the Way North Las Vegas Library District does Acquisitions-and Other Functions," Against the Grain 13, no. 2 (Apr. 2001): 72-75.

75. Frances C. Wilkinson and Linda K. Lewis, The Complete Guide to Acquisitions Management (Westport, Conn.: Libraries Unlimited, 2003).

76. Patricia A. Loghry and Amy W. Shannon, "Managing Selection and Implementation of Electronic Products: One Tiny Step in Organization, One Giant Step for the University of Nevada, Reno," Serials Review 26, no. 3 (2000): 32-44.

77. Ellen Finnie Duranceau and Cindy Hepfer, "Staffing for 
Electronic Resource Management: The Results of a Survey," Serials Review 28, no. 4 (Winter 2002): 316-20.

78. Sylvia M. Goldberg and Timothy McAdam, "A Collaborative Approach for Processing Electronic Resources at the University of California, Irvine," Technical Services Quarterly 20, no. 2 (2002): 21-32.

79. Richard P. Jasper, "Collaborative Roles in Managing Electronic Publications," Library Collections, Acquisitions, \& Technical Services 26, no. 4 (2002): 355-61.

80. David Ball, "Public Libraries and the Consortium Purchase of Electronic Resources," The Electronic Library 21, no. 4 (2003): 301-09.

81. Duncan E. Alford, "Negotiating and Analyzing Electronic License Agreements," Law Library Journal 94, no. 4 (2002): 621-44.

82. Kathryn Metzinger Miller, "Behind Every Great Virtual Library Stand Many Great Licenses," LibraryJournal.com (Jan. 15, 2003), www.libraryjournal.com/article/CA266431 .html (accessed June 17, 2008).

83. Rob Richards, "Licensing Agreements: Contracts, the Eclipse of Copyright, and the Promise of Cooperation," The Acquisitions Librarian 13 no. 26 (2001): 89-107.

84. John Blosser, "Vendors and Licenses: Adding Value for Customers," The Serials Librarian 38, no. 1/2 (2000): 14346.

85. Christine Urquhart, "Applications of Outsourcing Theory to Collaborative Purchasing and Licensing," VINE 32, no. 4 (2002): 63-70.

86. Timothy D. Jewell, Selection and Presentation of Commercially Available Electronic Resources: Issues and Practices (Washington, D.C.: Digital Library Federation, Council on Library and Information Resources, 2001).

87. Donald T. Hawkins, "Electronic Books: A Major Publishing Revolution: Part 1: General Considerations and Issues," Online 24, no. 4 (2000): 14-26, 28.

88. Ted Kruse and Allan Holtzman, "Web Booksellers-Their Usefulness to Libraries," Library Collections, Acquisitions, \& Technical Services 27, no. 1 (2003): 121-28.

89. David Gray and Malcolm H. Brantz, "Out of the Box and into the Bookstore: Non-Traditional Use of the Bookstore," Against the Grain 15, no. 3 (June 2003): 36, 38, 40, 42.

90. Ibid.

91. Michelle Flinchbaugh, "Biz of Acq: UMBC@BuyBooksFast. Com: Choosing and Using an Online Vendor to Improve Acquisitions Services," Against the Grain 13, no. 6 (Dec. 2001/Jan. 2002): 70-72.

92. Sydney K. Allen and Heather S. Miller, "Libraries on the Book Buying Merry-Go-Round: Internet Book Sellers vs. Library Book Vendor," Against the Grain 12, no. 2 (Apr. 2000): 1, 16-22.

93. L. Suzanne Kellerman, "Out-of-Print Digital Scanning: An
Acquisitions and Preservation Alternative," Library Resources \&Technical Services 46, no. 1 (Jan. 2002): 3-10.

94. Dan Tonkery, "Mergers and Acquisitions in the Library Marketplace: Opportunity or Threat?” Serials Review 27, no. 1 (2001): 45-50.

95. Ibid., 46.

96. Nancy Markle Stanley, "Biz of Acq: Book \& Serial Industry Mergers: Effects on Libraries," Against the Grain 12, no. 4 (Apr. 2002): 78-81.

97. Hendrik Edelman and Robert P. Holley, Marketing to Libraries for the New Millennium: Librarians, Vendors, and Publishers Review the Landmark Third Industry-Wide Survey of Library Marketing Practices and Trends (Lanham, Md.: Assocation for Library Collections \& Technical Services in cooperation with Scarecrow Pr., 2002).

98. David C. Fowler and Janet Arcand, "Monographs Acquisitions Time and Cost Studies: The Next Generation," Library Resources \& Technical Services 47, no. 3 (2003): 109-24.

99. Ibid., 116.

100. Ann Branton and Tracy Englert, "Mandate for Change: Merging Acquisitions and Cataloging Functions into a Single Workflow," Library Collections, Acquisitions, \& Technical Services 26, no. 4 (Winter 2002): 345-54.

101. Margaret Beecher Maurer and Michele L. Hurst, "LibraryVendor Collaboration for Re-Engineering Workflow: The Kent State Experience," Library Collections, Acquisitions, \& Technical Services 27, no. 2 (2003): 155-64.

102. Karen E. Greever, "Nuts and Bolts: Acquisitions and Cataloging at Kenyon," Library Collections, Acquisitions, \& Technical Services 27, no. 2 (Summer 2003): 147-54.

103. Thomas H. Marshall and Jennalyn Chapman Tellman, "Processing Foreign Language Books without Catalog Librarians at the University of Arizona Library," Against the Grain 12, no. 3 (June 2000): 28-29, 31, 26.

104. Rosann Bazirjian, "After Assessment: Application of the Results of an Acquisitions Teams Survey," Library Collections, Acquisitions, \& Technical Services 25, no. 4 (2001): 371-87.

105. Suzanne M. Ward, Tanner Wray, and Karl E. Debus-López, "Collection Development Based on Patron Requests: Collaboration Between Interlibrary Loan and Acquisitions," Library Collections, Acquisitions, \& Technical Services 27, no. 2 (2003): 203-13.

106. Ibid.

107. Megan Allen et al., "Patron-Focused Services in Three US Libraries: Collaborative Interlibrary Loan, Collection Development and Acquisitions," Interlending \& Document Supply 31, no. 2 (2003): 138-41.

108. Lorna Truck, "Plain English Collection Budgets: A Collection Plan for Public Libraries," The Bottom Line 15, no. 4 (2002): $167-73$.

109. Ibid., 168. 